L. GE, H. ZHOU, M.-F. CHIOU, H. JIANG, W. JIAN, C. YE, X. LI, X. ZHU, H. XIONG, Y. LI, L. SONG, X. ZHANG*, H. BAO* (PEKING UNIVERSITY, SHENZHEN; UNIVERSITY OF

CHINESE ACADEMY OF SCIENCES, BEIJING; CHINESE ACADEMY OF SCIENCES, FUZHOU, FUJIAN, P. R. OF CHINA)

Iron-Catalysed Asymmetric Carboazidation of Styrenes

Nat. Catal. 2021, 4, 28-35, DOI: 10.1038/s41929-020-00551-4.

\section{Iron-Catalyzed Asymmetric Carboazidation of Styrenes}

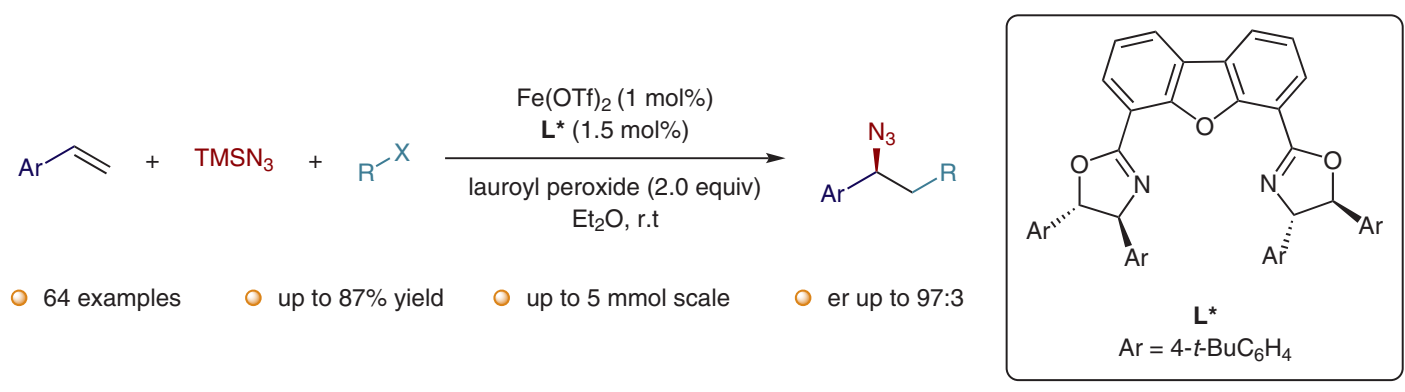<smiles>NC(CC(F)(F)F)c1cccc(Cl)c1</smiles>

$\mathrm{Br}$ er $=95: 5$<smiles>CC(C)(C)C[C@H](N)c1cc(Br)cc(Br)c1</smiles><smiles>NC(CC(Br)Br)c1cccc(Cl)c1</smiles>

$$
\begin{array}{rr}
\mathrm{R}=\mathrm{CO}_{2} \mathrm{Et} & \begin{array}{c}
87 \% \text { yield } \\
\text { er }=94: 6
\end{array} \\
\mathrm{R}=\mathrm{F} \quad \begin{array}{c}
76 \% \text { yield } \\
\text { er }=90: 10
\end{array}
\end{array}
$$

\section{Category}

Metals in Synthesis

\section{Key words}

iron catalysis

asymmetric

synthesis

difunctionalization

azides

\section{Synfact of the $u$ Month}

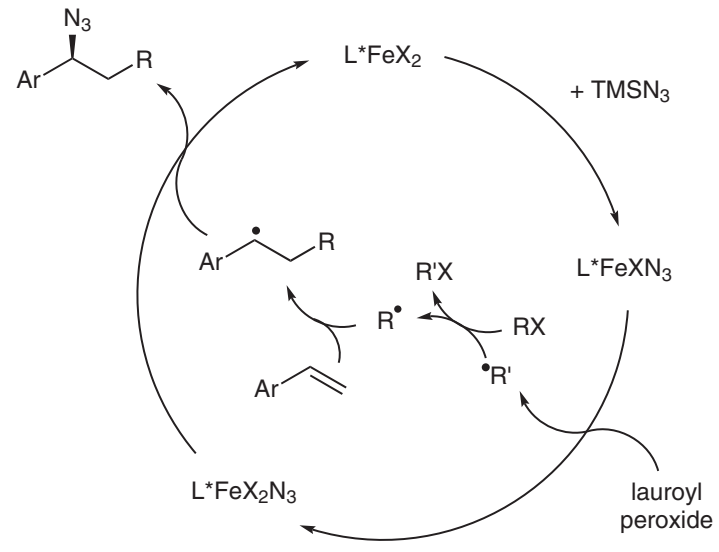

Significance: The authors report the use of a NON-pincer ligand for the asymmetric iron-catalyzed carboazidation reaction of styrenes. A variety of alkyl halides generating stabilized radicals were used.
Comment: A complex system involving synergistic effects of both van der Waals and $\pi$-interactions were found to be responsible for the stereocontrol of the reaction. 